\title{
The Influence of Ownership Structure, Debt Structure, and Independent Commissioner on Earning Management
}

\author{
Muhamad Yanuarsa $^{1,}$ Dwi Marlina Wijayanti ${ }^{1 *}$, Slamet \\ Haryono $^{1}$ \\ ${ }^{1}$ Faculty of Economics and Islamic Business, Sunan Kalijaga \\ State Islamic University Yogyakarta, Indonesia \\ *Corresponding author: dwi.wijayanti@,uin-suka.ac.id
}

Article history

Received, 20 August 2021

Revised 1, 07 Sept 2021

Accepted, 10 Nov 2021

\begin{abstract}
This study aims to examine the effect of independent commissioners, blockholder ownership, long-term debt, short-term debt, institutional ownership, family ownership, and managerial ownership on earnings management. This study is a quantitative study with a sample of 71 companies listed on the Indonesia Stock Exchange in 2017-2019. The data is processed by multiple regression using E-views. The results show that long-term debt has a negative effect on earnings management and short-term debt has a positive effect on earnings management. Other results show that independent board of commissioners, blockholder ownership, institutional ownership, family ownership, and managerial ownership do not cause earnings management. The limitation of this study is that it does not use a sample in the financial sector. Nevertheless, this research contributes practically and theoretically. This study also facilitates the weaknesses of previous research by adding variables of debt structure and ownership structure.
\end{abstract}

Keywords: Earning Management, Ownership Structure, Debt Structure, Independent Commissioner.

Cite this article:

Yanuarsa, M., Wijayanti, D.M., Haryono, S., (2021). The Influence of Ownership Structure, Debt Structure, and Independent Commissioner on Earning Management, Jurnal Al-Qardh, 6(2), 29-48. https://doi.org/10.23971/jaq.v6i2.3190

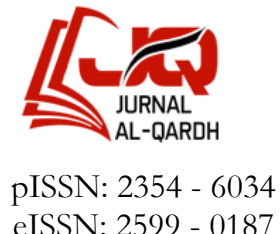

\section{Pendahuluan}

Maraknya aktivitas earnings management bukan menjadi persoalan baru di negara-negara Eropa dan Asia. Kasus manipulasi laporan keuangan sudah ada sebelumnya seperti Parmalat di Italia, Enron dan WorldCom di AS, hukum Benford di Taiwan, dan Indofarma di Indonesia ${ }^{1}$. Secara khusus jumlah kasus earnings management di Indonesia selalu ada setiap tahun. Hal ini dibuktikan dengan beberapa kasus seperti pemalsuan laporan keuangan di PT Garda Tujuh Buana tahun 2012, skandal akuntansi Tosiba tahun 2015, manipulasi laporan laba rugi PT Garuda Indonesia tahun 2018, dan manipulasi laporan keuangan di PT Asuransi

\footnotetext{
${ }^{1}$ Handriani, E. (2020). Earning management and the effect characteristics of audit committee, independent commissioners: Evidence from Indonesia. Research in World Economy. https://doi.org/10.5430/rwe.v11n3p108
} 
The Influence of Ownership Structure, Debt Structure, and

Independent Commissioner on Earning Management

Jiwasraya tahun $2020^{2}$. Praktik earnings management memiliki pengaruh yang mengkawatirkan karena menimbulkan efek buruk pada laporan keuangan dan pasar modal ${ }^{3}$.

Secara khusus, pada penelitian sebelumnya dari berbagai literatur menunjukkan inkonsistensi hasil mengenai hubungan antara earning management dengan sejumlah faktorfaktor yang memengaruhinya ${ }^{45}$. Oleh sebab itu, penelitian ini memiliki tingkat urgensi yang tinggi karena masih dibutuhkan pengembangan. Beberapa penelitian yang dilakukan oleh Dang et al., Haider, dan Hapsoro \& Bahantwelu menjelaskan bahwa ada banyak faktor yang diduga dapat memengaruhi tindakan earnings management seperti: dewan komisaris independen, blockholder ownership, hutang jangka panjang, hutang jangka pendek, kepemilikan institusional, kepemilikan keluarga, dan kepemilikan manajerial. ${ }^{678}$

Kemampuan yang dimiliki oleh dewan komisaris independen memberi pengaruh yang besar dari anggotanya terkait permintaan akan informasi keuangan yang tinggi'. Penelitian Saona et al. memiliki hasil bahwa dewan komisaris independen berpengaruh negatif terhadap earnings management. ${ }^{10}$ Namun pada penelitian Kjærland et al. memperoleh hasil bahwa dewan komisaris independen memiliki pengaruh positif pada earnings management. Hal ini sangat kontradiktif karena dewan komisaris independen seharusnya dapat memantau setiap aktivitas upaya eksekutif untuk menghindari adanya manipulasi akuntansi. ${ }^{11}$

Masalah yang dihadapi selanjutnya adalah kepemilikan saham suatu perusahaan dengan jumlah besar atau blockholder ownership. Blockholder ownership seringkali dapat memengaruhi kebijakan perusahaan yang diperoleh dari besarnya saham yang dimiliki. Menurut Edmans, blockholder ownership memiliki peran dalam mengelola perusahaan karena memiliki hak suara dalam menentukan strategi perusahaan. ${ }^{12}$ Pemegang saham akan mengeluarkan biaya monitoring yang diperlukan jika mereka memiliki kepemilikan saham yang cukup besar seperti blockholder. Oleh karena itu, adanya peran monitoring ini, blockholder dapat berfungsi

\footnotetext{
2 Laut, I. M. (2020). The Beauty and the Beast of Earning Management in Indonesia. Opción, 31, https://www.produccioncientificaluz.org/index.php/opcion/article/view/32496/33959

3 Alhadab, M., Abdullatif, M., \& Mansour, I. (2020). Related party transactions and earnings management in Jordan: the role of ownership structure. Journal of Financial Reporting and Accounting. https://doi.org/10.1108/JFRA-01-2019-0014

${ }^{4}$ Kjærland, F., Haugdal, A. T., Søndergaard, A., \& Vågslid, A. (2020). Corporate Governance and Earnings Management in a Nordic Perspective: Evidence from the Oslo Stock Exchange. Journal of Risk and Financial Management. https://doi.org/10.3390/jrfm13110256

5 Saona, P., Muro, L., \& Alvarado, M. (2020). How do the ownership structure and board of directors' features impact earnings management? The Spanish case. Journal of International Financial Management and Accounting. https://doi.org/10.1111/jifm.12114

${ }^{6}$ Dang, N. H., Hoang, T. V. H., \& Tran, M. D. (2017). Factors affecting earnings management: The case of listed firms in Vietnam. International Journal of Economic Research

${ }^{7}$ Haider, W. (2020). Factors Affecting Earnings Management: Evidence From Banking Sectors Of Pakistan. International Journal of Scientific \& Engineering Research

${ }^{8}$ Hapsoro, D., \& Bahantwelu, M. I. (2020). Does earning management mediate the effect of capital structure on company value? Jurnal Ekonomi Dan Bisnis. https://doi.org/10.24914/jeb.v23i1.2531

9 Pucheta-Martínez, M. C., \& García-Meca, E. (2014). Institutional investors on boards and audit committees and their effects on financial reporting quality. Corporate Governance: An International Review. https://doi.org/10.1111/ corg.12070

${ }^{10}$ Saona, P., Muro, L., \& Alvarado, M. (2020). How do the ownership structure and board of directors' features impact earnings management? The Spanish case. Journal of International Financial Management and Accounting. https://doi.org/10.1111/jifm.12114

${ }^{11}$ Kjærland, F., Haugdal, A. T., Søndergaard, A., \& Vågslid, A. (2020). Corporate Governance and Earnings Management in a Nordic Perspective: Evidence from the Oslo Stock Exchange. Journal of Risk and Financial Management. https://doi.org/10.3390/jrfm13110256

${ }^{12}$ Edmans, A. (2014). Blockholders and corporate governance. In Annual Review of Financial Economics. https://doi.org/10.1146/annurev-financial-110613-034455
} 
meningkatkan kualitas pelaporan keaungan perusahaan yang diproksikan dengan earnings management. Di sisi lain, semakin kecil blockholder ownership maka semakin tingginya kebijakan hutang. Hal ini berarti semakin kecil blockholder yang memegang saham atau semakin besar pengendalian saham oleh sebagian kecil perusahaan, maka semakin tinggi pula tingkat keberanian mereka dalam melakukan pinjaman atau hutang ${ }^{13}$.

Hutang digunakan untuk pembiayaan struktur modal ${ }^{14}$. Terdapat 2 kategori pembiayaan hutang yaitu hutang jangka panjang dan hutang jangka pendek. Adanya hubungan antara hutang jangka panjang dengan akrual yang ditentukan oleh kebijakan akan menciptakan kreditor suatu perusahaan tertarik untuk membatasi earnings management ${ }^{15}$. Penelitian Wang \& Lin menjelaskan bahwa kewajiban jangka panjang berpengaruh negatif signifikan pada aktivitas earnings management ${ }^{16}$. Kreditor perusahaan tertarik untuk memantau aktivitas hutang jangka panjang dibandingkan hutang jangka pendek, sehingga perlakuan ini membatasi manajer terhadap earnings management. Selain itu, temuan pengaruh hutang jangka pendek terhadap earnings management cukup tidak konsisten dibandingkan hutang jangka panjang ${ }^{17}$.

Hutang jangka pendek lebih cenderung memperburuk risiko likuiditas dibandingkan dengan hutang jangka panjang. Hal ini juga terdapat hubungan korelasi positif antara hutang jangka pendek dengan manipulasi laba yang harus lebih tinggi dibandingkan dengan hubungan secara insentif antara hutang umum dan earnings management ${ }^{18}$. Hutang jangka pendek memberikan dampak positif terhadap praktik earnings management ketika peringkat kelayakan kredit tidak diragukan. Artinya, jika kelayakan kredit perusahaan diragukan maka dibutuhkan perhatian lebih mengenai sejauh mana manajer melakukan manipulasi akrual agar terhindar dari berbagai penyimpangan dan pengingkaran perjanjian pada kontrak hutang ${ }^{19}$.

Kepemilikan institusional menjalankan peran utama yang signifikan dalam penataan tata kelola perusahaan ${ }^{20}$. Kepemilikan insttusional lebih berani dan mampu berperan dalam memantau, mendisiplinkan aktivitas manajerial, dan meningkatkan asimetri informasi di pasar modal21. Penelitian Roodposhti \& Chashmi menjelaskan bahwa kepemilikan institusional mampu memberikan kekuatan untuk membatasi perilaku oportunistik manajer dalam melakukan earnings management ${ }^{2}$. Berbeda dengan penelitian Hsu \& Wen yang

13 Wiliandri, R. (2011). Pengaruh blockholder ownership dan firm size terhadap kebijakan utang perusahaan. Jurnal Ekonomi Bisnis.

${ }^{14}$ Rey, A., Tuccillo, D., \& Roberto, F. (2020). Earnings management and debt maturity: Evidence from Italy. Corporate Ownership and Control. https://doi.org/10.22495/cocv17i3art14

15 Ilmas, F., Tahir, S., \& Asrar-ul-Haq, M. (2018). Ownership structure and debt structure as determinants of discretionary accruals: An empirical study of Pakistan. Cogent Economics and Finance. https://doi.org/10.1080/23322039.2018.1439254

16 Wang, H. Da, \& Lin, C. J. (2013). Debt financing and earnings management: An internal capital market perspective. Journal of Business Finance and Accounting. https://doi.org/10.1111/jbfa.12030

17 Nguyen, L. (2020). Short Term Debt Maturity, Real Earnings Management and Firm Performance Short Term Debt Maturity, Real Earnings Management and Firm Performance. May

${ }_{18}$ Trung, T. Q., Liem, N. T., \& Thuy, C. T. M. (2020). The impact of short-term debt on accruals-based earnings management-evidence from Vietnam. Cogent Economics and Finance, 8(1). https://doi.org/10.1080/23322039.2020.1767851

${ }_{19}$ Surya, B. J. M. H. (2017). Studi Pengaruh Short-Term Debt Dan Earnings Management Pada Badan Usaha Yang Terdaftar Di Bei Dan Pefindo Tahun 2011 - 2013. Jurnal Ilmiah Mahasiswa Universitas Surabaya

${ }^{20}$ Lskavyan, V., \& Spatareanu, M. (2011). Shareholder protection, ownership concentration and FDI. Journal of Economics and Business. https://doi.org/10.1016/j.jeconbus.2010.05.002

${ }^{21}$ Shah, K., \& Shah, A. (2014). The Impact of Corporate Governance and Ownership Structure on Earnings Management Practices: Evidence from Listed Companies in Pakistan. The Laboure Journal of Economics. https://doi.org/10.35536/lje.2014.v19.i2.a2

${ }^{22}$ Roodposhti, F. R., \& Chashmi, S. A. N. (2011). The impact of corporate governance mechanisms on earnings management. African Journal of Business Management, 5(11), 4143-4151. https://doi.org/10.5897/AJBM10.471 
The Influence of Ownership Structure, Debt Structure, and

Independent Commissioner on Earning Management

menyatakan bahwa dengan meningkatnya saham ekuitas yang dimiliki oleh investor institusional, manajer terpengaruh untuk mengelola akrual sehingga memperoleh kepentingan oportunistik jangka pendek. ${ }^{23}$

Kepemilikan keluarga didefinisikan sebagai kepemilikan dengan agregat jumlah hak milik keluarga setidaknya 10\% dari total saham dan satu atau lebih direktur pada struktur dewan yang berasal dari keluarga yang sama ${ }^{24}$. Perusahaan milik keluarga yang dominan tentu akan menunjuk anggota keluarga pada posisi teratas perusahaan. Hal ini menjadikan kepemilikan keluarga dianggap memainkan peran penting dalam kualitas laba yang tinggi sehingga manajer mungkin mamanipulasi pendapatan untuk mencapai bonus yang diinginkan ${ }^{25}$.

Selain faktor yang disebutkan, kepemilkan manajerial juga dapat memengaruhi earnings management. Penelitian Ilmas et al. menjelaskan bahwa kepemilikan manajerial mengontrol biaya pemantauan perusahaan yang berpengaruh positif pada earnings management ${ }^{26}$. Tingkat kepemilkan manajerial yang semakin tingggi akan cenderung memainkan jumlah laba, karena rendahnya tingkat kedisiplinan pasar ini dapat mengarah orang untuk membuat pilihan akuntansi demi menciptakan motif pribadi dibandingkan ekonomi perusahaan ${ }^{27}$.

Berdasarkan penjelasan di atas, maka penelitian ini bertujuan untuk menguji pengaruh dewan komisaris independen, blockholder ownership, hutang jangka panjang, hutang jangka pendek, kepemilikan institusional, kepemilikan keluarga, kepemilikan manajerial, terhadap earning management.

\section{Literatur Review dan Pengembangan Hipotesis Agency Theory}

Jensen \& Meckling mendefinisikan hubungan keagenan sebagai kesepakatan atau kontrak dari satu atau sebagian orang (principel) yang mempekerjakan orang lain (agent) dalam melaksanakan aktivitas yang mengatasnamakan pendelegasian wewenang dalam mengambil keputusan $^{28}$. Pada praktiknya di perusahaan, ternyata agen dalam kegiatannya terkadang tidak sesuai dengan kontrak kerja yang disepakati di awal tahun untuk meningkatkan kesejahteraan pemegang saham, melainkan cenderung berambisi untuk mendapatkan keuntungan pribadi. Menurut Bathala et al., tindakan ini disebut sebagai rasionalitas terbatas (bounded rationality) dan tidak suka mengambil resiko atau risk averse ${ }^{29}$.

\section{Shari'ah Enterprise Theory}

\footnotetext{
${ }^{23}$ Hsu, M.-F., \& Wen, S.-Y. (2015). The Influence of Corporate Governance in Chinese Companies on Discretionary Accruals and Real Earnings Management. Asian Economic and Financial Review. https://doi.org/10.18488/journal.aefr/2015.5.3/102.3.391.406

${ }^{24}$ Kurmann, A., Keller, S., Tschan-Semmer, F., Seelandt, J., Semmer, N. K., Candinas, D., \& Beldi, G. (2014). Impact of team familiarity in the operating room on surgical complications. World Journal of Surgery. https://doi.org/10.1007/s00268-014-2680-2

25 Ung, L. J., Brahmana, R. K., \& Puah, C. H. (2018). Brokerage fee, ownership expropriation and earnings management of Malaysian property companies. Property Management. https://doi.org/10.1108/PM-06-20170035

${ }^{26}$ Ilmas, F., Tahir, S., \& Asrar-ul-Haq, M. (2018). Ownership structure and debt structure as determinants of discretionary accruals: An empirical study of Pakistan. Cogent Economics and Finance. https://doi.org/10.1080/23322039.2018.1439254

27 O’Callaghan, S., Ashton, J., \& Hodgkinson, L. (2018). Earnings management and managerial ownership in private firms. Journal of Applied Accounting Research. https:// doi.org/10.1108/JAAR-11-2017-0124

28 Jensen, M. C., \& Meckling, W. H. (1976). Theory of the firm: Managerial behavior, agency costs and ownership structure. Journal of Financial Economics. https://doi.org/10.1016/0304-405X(76)90026-X

${ }^{29}$ Bathala, C. T., Moon, K. P., \& Rao, R. P. (1994). Managerial Ownership, Debt Policy, and the Impact of Institutional Holdings: An Agency Perspective. Financial Management. https://doi.org/10.2307/3665620
} 
Di dalam akuntansi, shariah enterprise theory berfungsi untuk menyajikan laporan keuangan dengan cara memberikan informasi mengenai nilai tambah yang berhasil diciptakan perusahaan dan bagaimana perusahaan mendistribusikan kepada pihak-pihak yang memiliki hak untuk menerimanya tanpa ada manipulasi. Perlakuan tersebut sesuai dengan ajaran Islam, sebagaimana firman Allah yang terkandung pada surat Al-Muthaffifin (83) ayat 1-3 berikut:

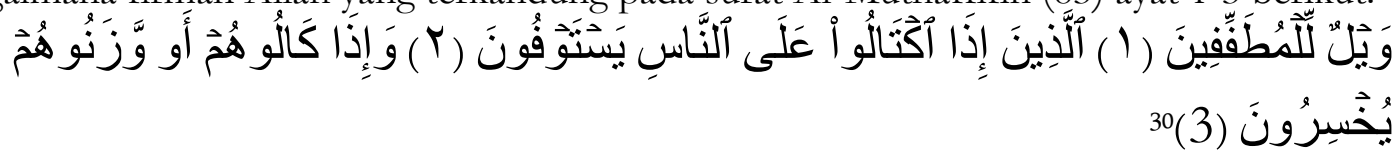

Menurut Tafsir Ibnu Katsir, makna dari QS. Al-Muthaffifin (83) ayat 1-3 yaitu Allah telah mengutus umatnya agar memenuhi takaran dan timbangan dengan penuh keadilan, kebenaran, kejujuran, dan tidak memanipulasi karena menimbulkan kerugian beberapa pihak $^{31}$. Selain itu, adanya shari'ah enterprise theory ini memberikan dimensi akuntabilitas vertikal atas sumber daya yang digunakan perusahaan dalam menghasilkan produk untuk dijual dan mengambil manfaat ekonomi bagi penggunanya, yaitu tanggung jawab kepada Tuhan ${ }^{32}$.

\section{Earning Management}

Earning management merupakan proses pengambilan berbagai upaya secara sengaja dalam batas prinsip akuntansi yang diterima umum guna mendapatkan tingkat laba yang dilaporkan ${ }^{33}$. Praktik earnings management ini terjadi karena ada motivasi dalam memaksimalkan laba, pemenuhan ekspetasi pemegang saham, menghindari pelanggaran hutang, dan untuk memaksimalkan remunerasi demi kepentingan pribadi ${ }^{34}$. Tujuan utama dari earnings management yaitu untuk menunjukkan kualitas laba progresif yang dapat memenuhi persyaratan dalam memperolah otoritas yang relevan dari regulator atau harapan pemegang saham $^{35}$.

\section{Dewan Komisaris Independen}

Menurut Saona et al. , dewan komisaris independen adalah kumpulan komisars eksternal yang tidak mempunyai suatu ikatan keuangan atau ikatan pengelolaan dengan dewan komisaris lain sehingga memberikan kontribusi positif untuk tugas pengawasan dewan ${ }^{36}$. Selain itu, dewan komisaris independen juga memiliki fungsi yang penting dalam menentukan keputusan struktur permodalan pada perusahaan. Perusahaan dengan komisaris

\footnotetext{
${ }^{30}$ Artinya: "1. Celakalah bagi orang-orang yang curang (dalam menakar dan menimbang); 2. (Yaitu) orang-orang yang apabila menerima takaran dari orang lain mereka minta dicukupkan; 3. dan apabila mereka menakar atau menimbang (untuk orang lain), mereka mengurangi." https://quranindo.com/surat-al-mutaffifin/ diakses pada tanggal 28 Juli 2021 jam 19.40

${ }^{31}$ http://www.ibnukatsironline.com/2015/10/tafsir-surat-al-muthaffifin-ayat-1-6.html diakses pada tanggal 2 Januari 2021 jam $23.12 \mathrm{WIB}$

32 Pramiana, O., \& Anisah, N. (2018). Implementasi Corporate Social Responsibility (CSR) Dalam Perspektif Shariah Enterprise Theory. EKSIS

33 alacios-Manzano, M., Gras-Gil, E., \& Santos-Jaen, J. M. (2021). Corporate social responsibility and its effect on earnings management: an empirical research on Spanish firms. In Total Quality Management and Business Excellence. https://doi.org/10.1080/14783363.2019.1652586

${ }^{34}$ Ghazali, A. W., Shafie, N. A., \& Sanusi, Z. M. (2015). Earnings Management: An Analysis of Opportunistic Behaviour, Monitoring Mechanism and Financial Distress. Procedia Economics and Finance. https://doi.org/10.1016/s2212-5671(15)01100-4

35 Saleh, I., Afifa, M. A., \& Haniah, F. (2020). Financial factors affecting earnings management and earnings quality: New evidence from an emerging market. ACRN Journal of Finance and Risk Perspectives. https://doi.org/10.35944/JOFRP.2020.9.1.014

${ }^{36}$ Saona, P., Muro, L., \& Alvarado, M. (2020). How do the ownership structure and board of directors' features impact earnings management? The Spanish case. Journal of International Financial Management and Accounting. https://doi.org/10.1111/jifm.12114
} 
The Influence of Ownership Structure, Debt Structure, and

Independent Commissioner on Earning Management

yang lebih independen akan berpengaruh besar dalam memberikan keuntungan yang maksimal bagi pemegang saham ${ }^{37}$.

\section{Blockholder Ownership}

Thomsen et al. mendefinisikan blokholder ownership sebagai kepemilikan dengan jumlah lebih dari 5\% saham yang dimiliki direktur, karyawan, anggota keluarga, perusahaan lain seperti perusahaan yang sedang digadaikan, dan saham bank ${ }^{38}$. Kehadiran blockholder ownership mendorong manajer agar melaporkan informasi keuangan dan memiliki ancaman intervensi yang lebih besar dibandingkan dengan pemegang saham minoritas. Hal ini menyebabkan adanya insentif bagi manajer untuk mengurangi laba, khususnya pada perusahaan yang sedang mengalami penurunan kinerja. Jumlah kepemilikan saham yang semakin tinggi dari blockholder, maka akan semakin berani mereka dalam mengambil pinjaman atau memperbesar kebijakan hutang.

\section{Hutang Jangka Panjang}

Hutang jangka panjang merupakan wujud perjanjian atau kesepakatan antara kreditur dengan pemberi pinjaman bahwa pemberi pinjaman bersedia memberikan pinjaman dana dalam jumlah tertentu dan peminjam berkewajiban membayarnya secara berkala meliputi bunga dan pokok pinjaman ${ }^{39}$. Umumnya hutang jangka panjang berfungsi untuk keperluan dalam jumlah besar seperti ekspansi atau modernisasi perusahaan. Menurut Ilmas et al. , adanya hubungan antara hutang jangka panjang dengan akrual yang ditentukan oleh kebijakan menciptakan kreditor suatu perusahaan tertarik untuk membatasi earnings management ${ }^{0}$.

\section{Hutang Jangka Pendek}

Hutang jangka pendek didefinisikan sebagai kewajiban keuangan perusahaan dengan waktu maksimum satu tahun dan pelunasan pembayaran menggunakan aset lancar yang dimiliki perusahaan ${ }^{41}$. Hampir sejumlah hutang jangka pendek diperoleh dari kredit perdagangan barang atau jasa yang merupakan kredit yang dibutuhkan ketika menjalankan suatu bisnis atau usaha. Di sisi lain, hutang jangka pendek kondusif untuk risiko likuiditas dibandingkan dengan hutang jangka panjang.

\section{Kepemilikan Institusioanal}

Menurut Bao \& Lewellyn, kepemilkan institusional merupakan presentase saham beredar perusahaan yang dipegang oleh pemilik institusional seperti bank, reksadana, dan perusahaan asuransi $i^{42}$. Kepemilikan institusional berperan penting dalam uaya pemantauan dan pendisiplinan aktivitas manajerial serta dapat meningkatkan asimetri informasi di pasar modal. Kepemilikan institusioanl dapat difungsikan sebagai alat untuk mengurangi konflik

\footnotetext{
37 Wahidah, S. A., \& Ardiansari, A. (2019). The Effect of Board of Commissioners and Independent Commissioners on Agency Cost Through Capital Structure. Management Analysis Journal.

38 Thomsen, S., Pedersen, T., \& Kvist, H. K. (2006). Blockholder ownership: Effects on firm value in market and control based governance systems. Journal of Corporate Finance. https://doi.org/10.1016/j.jcorpfin.2005.03.001

${ }^{39}$ Maulana, Z., \& Safa, A. F. (2017). Pengaruh Hutang Jangka Pendek Dan Hutang Jangka Panjang Terhadap Profitabilitas Pada PT. Bank Mandiri Tbk. Penelitian Ekonomi Akuntansi.

40 Ilmas, F., Tahir, S., \& Asrar-ul-Haq, M. (2018). Ownership structure and debt structure as determinants of discretionary accruals: An empirical study of Pakistan. Cogent Economics and Finance. https://doi.org/10.1080/23322039.2018.1439254

${ }^{41}$ Maulana, Z., \& Safa, A. F. (2017). Pengaruh Hutang Jangka Pendek Dan Hutang Jangka Panjang Terhadap Profitabilitas Pada PT. Bank Mandiri Tbk. Penelitian Ekonomi Akuntansi.

${ }^{42}$ Bao, S. R., \& Lewellyn, K. B. (2017). Ownership structure and earnings management in emerging marketsAn institutionalized agency perspective. International Business Review. https://doi.org/10.1016/j.ibusrev.2017.02.002
} 
keagenan ${ }^{43}$. Di sisi lain, investor institusional dapat membantu sumber pendanaan suatu perusahaan untuk melakukan pengembangan bisnis ${ }^{44}$.

\section{Kepemilikan Keluarga}

Menurut Ilmas et al., kepemilikan keluarga merupakan kepemilikan yang didalamnya merupakan anggota keluarga sedarah sebagai pejabat, direktur, blockholder, (baik individu atau sebagai kelompok $)^{40}$. Kepemilikan keluarga biasanya secara aktif terlibat dalam manajemen perusahaan seperti menjabat sebagai eksekutif atau bahkan direktur, sehingga hal ini tentu memperkecil konflik keagenan antara manajemen dan pemegang saham. Menurut Bendickson et al. masalah keagenan terjadi seperti kecenderungan keluarga untuk menunjuk anggota keluarga ke posisi teratas tanpa meperhatikan kualifikasinya atas dasar pemegang saham mayoritas ${ }^{45}$. Keputusan tersebut dilakukan oleh anggota keluarga yang mempunyai wewenang melebihi hak arus kas mereka, sehingga membatasi penyelarasan risiko.

\section{Kepemilikan Manajerial}

Menurut Rashid, kepemilikan manajerial diartikan sebagai kepemilikan yang presentase sahamnya dikendalikan oleh direksi dan atau eksekutif perusahaan ${ }^{46}$. Kepemilikan manajerial mampu memberikan efek positif pada keputusan investasi perusahaan, mengurangi tingkat kendala keuangan, dan membantu mengurangi masalah keagenan serta informasi asimetris ${ }^{47}$. Ketika kontrak yang dihasilkan oleh kebijakan manajerial tidak lengkap, maka peluang investasi tidak dapat diamati secara sempurna, sehingga solusinya adalah memberikan insentif kepada manajer dalam bentuk saham ekuitas ${ }^{48}$.

\section{Pengembangan Hipotesis}

\section{Dewan komisaris independen dan earning management}

Puspitasari \& Emy menemukan bukti bahwa dewan komisaris independen berpengaruh positif terhadap earnings management. Hal ini terjadi karena manajemen laba meningkat sejalan dengan presentase independensi dewan ${ }^{49}$. Kjærland et al. menambahkan bahwa masalah ini terjadi karena dewan komisaris independen hanya bertindak sesuai dengan standar legislatif dan pencatatan bursa yang berkembang, sehingga tidak memiliki independensi dalam pemikiran dan tindakan kualitatif ${ }^{50}$. Berbeda dengan penelitian yang dilakukan oleh Nanda \& Somantri yang memperoleh hasil bahwa dewan komisaris independen tidak memiliki pengaruh terhadap earnings management ${ }^{51}$. Penyebab utamanya

\footnotetext{
${ }^{43}$ Khan, M., Srinivasan, S., \& Tan, L. (2017). Institutional ownership and corporate tax avoidance: New evidence. Accounting Review. https://doi.org/10.2308/accr-51529

${ }^{44}$ Lin, Y. R., \& Fu, X. M. (2017). Does institutional ownership influence firm performance? Evidence from China. International Review of Economics and Finance. https://doi.org/10.1016/j.iref.2017.01.021

${ }^{45}$ Bendickson, J., Muldoon, J., Liguori, E., \& Davis, P. E. (2016). Agency theory: the times, they are a-changin'. Management Decision. https://doi.org/10.1108/MD-02-2015-0058

46 Rashid, A. (2016). Managerial Ownership and Agency Cost: Evidence from Bangladesh. Journal of Business Ethics. https://doi.org/10.1007/s10551-015-2570-z

${ }^{47}$ Vijayakumaran, R. (2021). Impact of managerial ownership on investment and liquidity constraints: Evidence from Chinese listed companies. Research in International Business and Finance. https://doi.org/10.1016/j.ribaf.2020.101321

${ }^{48}$ Dixon, R., Guariglia, A., \& Vijayakumaran, R. (2017). Managerial ownership, corporate governance and firms' exporting decisions: Evidence from Chinese listed companies. European Journal of Finance. https://doi.org/10.1080/1351847X.2015.1025990

49 Puspitasari Puji, Emy., D. (2019). Pengaruh Faktor Good Corporate Governance, Free Cash Flow, dan Leverage Terhadap Manajemen Laba Pada Perusahaan Batu Bara. E-Jra.

${ }^{50}$ Kjærland, F., Haugdal, A. T., Søndergaard, A., \& Vågslid, A. (2020). Corporate Governance and Earnings Management in a Nordic Perspective: Evidence from the Oslo Stock Exchange. Journal of Risk and Financial Management. https://doi.org/10.3390/jrfm13110256

${ }^{51}$ Nanda, L. N., \& Somantri, Y. F. (2020). Pengaruh Komisaris Independen Terhadap Manajemen Laba Pada Perusahaan Bank Yang Terdaftar Di Bursa Efek Indonesia. Jrka.
} 
The Influence of Ownership Structure, Debt Structure, and

Independent Commissioner on Earning Management

adalah penambahan atau penempatan dewan komisaris independen hanya sebatas untuk meningkatkan citra perusahaan dan pemenuhan regulasi saja ${ }^{52}$. Berdasarkan perspektif shari'ah enterprise theory bahwasannya dewan komisaris independen harus menjalankan tugas dengan bijak seperti berperilaku adil terhadap pemegang saham minoritas dan pemangku kepentingan lainnya karena hal ini akan dipertanggungjawabkan dihadapan Tuhan ${ }^{53}$.

Menurut Syahreza et al. semakin besar komposisi dewan komisaris independen maka akan mengurangi earnings management ${ }^{54}$. Hal ini menjelaskan bahwa keberadaaan dewan komisaris independen mampu memperkecil konflik manajeman dan akan memberikan nilai lebih bagi pihak yang bersangkutan ${ }^{55}$. Susanto juga menambahkan bahwa adanya dewan komisaris independen menjadi penyeimbang dalam upaya melindungi pemegang saham minoritas dan pihak lain yang mempunyai hubungan dengan perusahaan ${ }^{56}$.

Berdasarkan uraian ini, maka hipotesis yang dapat dikembangkan adalah:

H1: Dewan Komisaris Independen berpengaruh negatif terhadap earnings management

\section{Blockholder ownership dan earning management}

Jiang et al., membuktikan bahwa blockholder ownership berpengaruh positif terhadap earnings management ${ }^{57}$. Halioui \& Jerbi juga memperoleh hasil yang sama bahwasanya blockholder ownership berpengaruh terhadap earnings management karena saham ekuitas yang dimiliki oleh pejabat puncak atau sebagai pemegang saham terbesar perusahaan mendorong perilaku oportunistik untuk melakukan earnings manaagement ${ }^{58}$. Berbeda dengan penelitian Zulvina bahwa blockholder tidak memiliki pengaruh pada earnings management, alasannya adalah para pemegang blockholder ownership tidak mendapatkan wewenang lebih dari perusahaan untuk memengaruhi berbagai aspek dalam pergerakan dan keputusan perusahaan ${ }^{59}$.

Penelitian lain seperti Jerbi \& Halioui memperoleh hasil bahwa kehadiran blockholder ownership dapat meringankan konsekuensi negatif dari masalah keagenan ${ }^{60}$. Hal ini sesuai dengan teori agensi bahwa blockholder ownership dipandang sebagai aktivis yang lebih memperhatikan keputusan manajerial dan akan mengurangi earnings management ${ }^{61}$.

Berdasarkan uraian ini, maka hipotesis yang dapat dikembangkan adalah: H2: Blockholder ownership berpengaruh negatif terhadap earnings management

\footnotetext{
52 Widyastuti, D. I. (2018). Pengaruh Kepemilikan Manajerial, Kepemilikan Institusional, dan Proporsi Dewan Komisaris Independen terhadap Manajemen Laba. JEBDEER: Journal of Entrepreneurship, Business Development and Economic Educations Research. https://doi.org/10.32616/jbr.v1i2.64

53 Abdullah, Y., \& Nugraha, A. W. (2020). Implementasi Akuntabilitas Berdasarkan Pada Perspektif Sharia Enterprise Theory (Studi Kasus pada Koperasi Syariah Mumtaz Tasikmalaya). Jurnal Ekonomi Syariah.

${ }^{54}$ Syahreza, F., Pratomo, D., \& Yudowati, S. (2016). Pengaruh Komisaris Independen dan Komite Audit Terhadap Manajemen Laba ( Studi Empiris Pada Perusahaan Manufakur Sub Sektor Makanan dan Minuman yang Terdaftar di dalam Bursa Efek Indonesia Tahun 2010-2013 ). E-Proceeding of Management.

55 Handriani, E. (2020). Earning management and the effect characteristics of audit committee, independent commissioners: Evidence from Indonesia. Research in World Economy. https://doi.org/10.5430/rwe.v11n3p108 56 Susanto, Y. K. (2016). The Effect of Audit Committees and Corporate Governance on Earnings Management: Evidence From Indonesia Manufacturing Industry. International Journal of Business, Economics and Law.

57 Jiang, F., Ma, Y., \& Wang, X. (2020). Multiple blockholders and earnings management. Journal of Corporate Finance. https://doi.org/10.1016/j.jcorpfin.2020.101689

${ }^{58}$ Halioui, K., \& Jerbi, A. (2012). The effect of blockholders on earnings-management: the case of Tunisian listed firms. International Journal of Multidisciplinary Research

${ }^{59}$ Zulvina, Y. (2015). Pengaruh Komisaris Independen, Komite Audit dan Blockholders Terhadap Earnings Management. Jom FEKON

${ }^{60}$ Jerbi Maatougui, A., \& Halioui, K. (2019). The effect of outside blockholders on earnings management around seasoned equity offerings in French listed companies on the SBF120. Journal of Financial Reporting and Accounting. https://doi.org/10.1108/JFRA-02-2018-0012

${ }^{61}$ Kapkiyai, C., Cheboi, J., \& Komen, J. (2020). Shareholder Activism and Earnings Management: Evidence from Kenya. African Journal of Education, Science and Technology.
} 


\section{Struktur hutang dan earning management}

Surya membuktikan bahwa hutang jangka pendek membantu mengurangi biaya agensi dan dapat mengurangi earnings management ${ }^{62}$. Namun, penelitian Ilmas et al. memperoleh hasil bahwa hutang jangka pendek berpengaruh positif terhadap earnings management, sedangkan hutang jangka panjang berpengaruh negatif terhada earnings management $t^{3}$. Hutang jangka panjang yang tinggi dapat meningkatkan pengawasan yang ketat oleh peminjam, sehingga manajer akan mengindari motivasi untuk melakukan pelanggaran perjanjian. Pada jatuh tempo hutang jangka pendek, akan memiliki kemungkinan memberi dampak yang diinginkan dalam earnings management pada tingkat yang rendah. Sementara, pada tingkat yang tinggi cenderung meningkatkan earnings management ${ }^{64}$.

Sudut pandang teori agensi menjelaskan bahwa earnings management muncul ketika manajer memiliki keleluasaan untuk mengejar kepentingan sendiri seperti menyesatkan debtholder dalam keputusan pemberian pinjaman ${ }^{65}$. Pada prinsip shariab enterprise theory bahwasannya ketika pihak debitur memiliki hutang dengan pihak kreditur khususnya perlakuan pada hutang jangka panjang yang jumlahnya relatif besar seperti untuk pengembangan bisnis, harusnya tidak berperilaku curang dengan mengambil keuntungan pribadi karena hal ini tidak mencerminkan nilai kejujuran dan akuntabilitas ${ }^{66}$.

Berdasarkan uraian ini, maka hipotesis yang dapat dikembangkan adalah:

H3a: Hutang jangka panjang berpengaruh negatif terhadap earnings management

H3b: Hutang jangka pendek berpengaruh positif terhadap earnings management

\section{Kepemilikan institusional dan earning management}

Alexander membuktikan bahwa kepemilikan institusional berpengaruh negatif terhadap earnings management $t^{67}$. Affan et al. menjelaskan bahwa hal ini terjadi karena aktivitas yang dijalankan dalam kepemilikan institusional dapat menambah kualitas pelaporan keuangan dengan pengecekan manajemen yang pada akhirnya mengurangi konflik keagenan ${ }^{68}$. Tindakan ini juga mampu mengurangi keikutsertaan dalam earnings management ${ }^{69}$. Berdasarkan teori agensi, perusahaan dengan kepemilikan institusional yang lebih tinggi cenderung tidak mengelola pendapatan. Berbeda dengan penelitian yang dilakukan oleh Emmanuel et al., bahwa dengan meningkatnya saham ekuitas yang dimiliki oleh investor institusional, manajer terpengaruh untuk mengelola akrual sehingga memperoleh kepentngan oportunistik jangka pendek ${ }^{70}$.

${ }^{62}$ Surya, B. J. M. H. (2017). Studi Pengaruh Short-Term Debt Dan Earnings Management Pada Badan Usaha Yang Terdaftar Di Bei Dan Pefindo Tahun 2011 - 2013. Jurnal Imiah Mahasiswa Universitas Surabaya

${ }^{63}$ Ilmas, F., Tahir, S., \& Asrar-ul-Haq, M. (2018). Ownership structure and debt structure as determinants of discretionary accruals: An empirical study of Pakistan. Cogent Economics and Finance.

https://doi.org/10.1080/23322039.2018.1439254

${ }^{64}$ Trung, T. Q., Liem, N. T., \& Thuy, C. T. M. (2020). The impact of short-term debt on accruals-based earnings management-evidence from Vietnam. Cogent Economics and Finance, 8(1). https://doi.org/10.1080/23322039.2020.1767851

65 Park, S. Y. (2016). The effect of short-term debt on accrual based earnings management and real earnings management. Journal of Applied Business Research. https://doi.org/10.19030/jabr.v32i4.9737

${ }^{66}$ Abdullah, Y., \& Nugraha, A. W. (2020). Implementasi Akuntabilitas Berdasarkan Pada Perspektif Sharia Enterprise Theory (Studi Kasus pada Koperasi Syariah Mumtaz Tasikmalaya). Jurnal Ekonomi Syariah

${ }^{67}$ Alexander, N. (2019). Ownership Structure and Earnings Management. GATR Accounting and Finance Review. https://doi.org/10.35609/afr.2019.4.2(1)

68 Affan, M., Ak, R., \& Purwanti, L. (2017). The Effect of Ownership Structure on the Quality of Financial Reporting Of Manufacturing Companies Listed In the IDX during the Period of 2013-2015. Imperial Journal of Interdisciplinary Research (IJIR).

${ }^{69}$ Latif, A. \&, \& Abdullah Fahad. (2015). The Effectiveness of Corporate Governance in Constraining Earnings Management in Pakistan. The Labore Journal of Economics.

${ }^{70}$ Emmanuel, P., , Umoh, R. O., Afor, H., Roselyn, Zakaria sabe Zainab, \& . (2019). Effect of Ownership Structure on Earnings Management of Listed Industrial Goods Companies in Nigeria. Journal of Business and 
The Influence of Ownership Structure, Debt Structure, and

Independent Commissioner on Earning Management

Berdasarkan uraian ini, maka hipotesis yang dapat dikembangkan adalah:

H4: Kepemilikan institusional berpengaruh negatif terhadap earnings management

Kepemilikan keluarga dan earning management

Ung et al., membuktikan bahwa kepemilikan keluarga dianggap memainkan peran penting dalam kualitas laba yang tinggi sehingga manajer mungkin menerapkan earnings management untuk mencapai bonus yang diinginkan ${ }^{71}$. Berbeda dengan Martin et al., yang membuktikan bahwa kepemilikan keluarga berpengaruh negatif terhadap earnings management karena memiliki kecenderungan untuk memberikan peringatan pendapatan dan kawatir mengenai upaya melindungi reputasi ${ }^{72}$. Akhirnya, para pemilik saham keluarga lebih baik menjelaskan perbedaan yang ada dalam pengungkapa perkiraan pendapatan. Teori agensi menjelaskan bahwa konsentrasi kepemilikan keluarga akan menyebabkan asimetri informasi lebih rendah karena kurangnya pengetahuan pemilihan orang eksekutif yang kurang kompeten untuk memimpin perusahaan ${ }^{73}$.

Berdasarkan uraian ini, maka hipotesis yang dapat dikembangkan adalah:

H5: Kepemilikan keluarga berpengaruh negatif terhadap earnings management Kepemilikan manajerial dan earning management

Menurut Parveen et al., besar kecilnya kepemilikan saham manajerial tidak membatasi tindakan manajerial untuk memaksimalkan kepentingan-kepentingan yang menguntungkan diri sendiri sehingga berani untuk meakukan earnings management ${ }^{74}$. Sejalan dengan penelitian Ilmas et al. bahwa besarnya presentase kepemilikan manajerial, maka semakin besar juga kemungkinan munculnya aktivitas manipulasi laba ${ }^{75}$. Penelitian Anwar \& Buvanendra membuktikan bahwa kepemilikan manajerial berpengaruh negatif pada earnings management ${ }^{76}$. Hal ini timbul karena ketika manajer juga memiliki porsi kepemilikan saham, maka mereka akan bertindak sesuai dengan pemegang saham eksternal dan memastikan laporan keuangan yang disajikan wajar sesuai dengan kondisi sebenarnya ${ }^{77}$.

Berdasarkan uraian ini, maka hipotesis yang dapat dikembangkan adalah:

H6: Kepemilikan manajerial berpengaruh positif terhadap earnings management

\section{Metode Penelitian}

Penelitian ini adalah penelitian kuantitatif. Populasi menggunakan perusahaan non keuangan yang listing di Bursa efek Indonesia dari tahun 2017-2019. Periode ini dipilih karena pada tahun 2017-2019 banyak sekali terjadi kasus earnings management ${ }^{78}$. Total observasi yaitu 71 perusahaan. Teknik penentuan sampel menggunakan purposive sampling.

\footnotetext{
Management (IOSR-JBM).

${ }^{71}$ Ung, L. J., Brahmana, R. K., \& Puah, C. H. (2018). Brokerage fee, ownership expropriation and earnings management of Malaysian property companies. Property Management. https://doi.org/10.1108/PM-06-20170035

${ }^{72}$ Martin, G., Campbell, J. T., \& Gomez-Mejia, L. (2016). Family Control, Socioemotional Wealth and Earnings Management in Publicly Traded Firms. Journal of Business Ethics. https://doi.org/10.1007/s10551-014-2403-5

${ }^{73}$ Miller, D., Breton-Miller, I. Le, \& Lester, R. H. (2010). Family ownership and acquisition behavior in publiclytraded companies. Strategic Management Journal. https://doi.org/10.1002/smj.802

${ }^{74}$ Parveen, S., Malik, N., Mahmood, Y., \& Ali Jan, F. (2016). Impact of Ownership Structure on Earnings Management: Evidence from Pakistani Banking Sector. An International Peer-Reviewed Journal.

75 Ilmas, F., Tahir, S., \& Asrar-ul-Haq, M. (2018). Ownership structure and debt structure as determinants of discretionary accruals: An empirical study of Pakistan. Cogent Economics and Finance. https://doi.org/10.1080/23322039.2018.1439254

76 Anwar, H., \& Buvanendra, S. (2019). Earnings Management and Ownership Structure: Evidence from Sri Lanka. Colombo Business Journal. https://doi.org/10.4038/cbj.v10i1.42

77 Yahaya, I. D., Oyedokun, G. E., \& Aruwa, S. A. S. (2019). Effect of ownership structure on earnings management of listed consumer goods firms in Nigeria. Fountain University Osogbo Journal of Management.

${ }^{78}$ Handriani, E. (2020). Earning management and the effect characteristics of audit committee, independent
} 
Variabel dan Pengukuran Variabel

Earnings management diproksikan dengan descretionary accrual. Penelitian ini dilakukan dengan menggunakan Model Jones yang dimodifikasi karena memberikan hasil akrual diskresioner yang lebih akurat ${ }^{79}$. Model Jones yang dimodifikasi dinyatakan dalam rumus sebagai berikut: Discretionary accrual didapat dengan cara menghitung total akrual dengan rumus sebagai berikut:

$$
T A_{i t}=N I_{i t}-C F O_{i t}
$$

Tahap berikutnya yaitu melakukan dekomposisi komponen jumlah akrual kedalam kedalam komponen discretionary accrual dengan nondiscretionary accrual. Rumus yang terbentuk yaitu:

$$
\frac{T A_{i t}}{A_{i t-1}}=\beta_{1}\left(\frac{1}{A_{i t-1}}\right)+\beta_{2}\left(\frac{\Delta R e v_{i t}}{A_{i t-1}}\right)+\beta_{3}\left(\frac{P P E_{i t}}{A_{i t-1}}\right)+\varepsilon
$$

Setelah itu proses mendapatkan nilai nondiscretionary accrual yang diperoleh dengan rumus sebagai berikut:

$$
N D A_{i t}=\beta_{1}\left(\frac{1}{A_{i t-1}}\right)+\beta_{2}\left(\frac{\Delta \operatorname{Rev}_{i t}}{A_{i t-1}}-\frac{\Delta R e c_{i t}}{A_{i t-1}}\right)+\beta_{3}\left(\frac{P P E_{i t}}{A_{i t-1}}\right)
$$

Tahap akhir, discretionary accrual sebagai ukuran earnings management diperoleh dengan rumus sebagai berikut:

Keterangan:

$$
D A C_{i t}=\frac{T A_{i t}}{A_{i t-1}}-N D A_{i t}
$$

$D A C_{i t}=$ Discretionary accruals perusahaan i dalam periode tahun $\mathrm{t}$

$N D A_{i t}=$ Nondiscretionary accruals perusahaan i dalam periode tahun $\mathrm{t}$

$T A_{i t} \quad=$ Total akrual perusahaan i dalam periode tahun $\mathrm{t}$

$N I_{i t} \quad=$ Laba bersih perusahaan i dalam periode tahun $\mathrm{t}$

$C F O_{i t}=$ Arus kas dari aktivitas operasi perusahaan i dalam periode tahun $\mathrm{t}$

$A_{i t-1}=$ Total aset perusahaan i dalam periode tahun $\mathrm{t}$

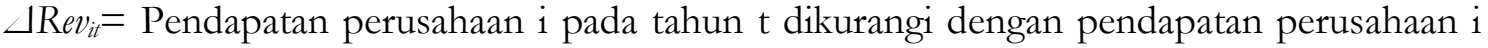
pada tahun $\mathrm{t}-1$

$P P E_{i t}=$ Plant, property, and equipment perusahaan i dalam periode tahun $\mathrm{t}$

$\Delta R e c_{i t}=$ Piutang usaha perusahaan i pada tahun t dikurangi pendapatan perusahaan i pada tahun t-1

$\varepsilon \quad=$ Error

Selanjutnya, dewan komisaris independen dihitung melalui presentase anggota dewan komisaris yang berasal dari eksternal perusahaan pada semua ukuran dewan komisaris perusahaan sampel. Selain komisarin independent, Hutang jangka panjang diukur dari kewajiban jangka panjang dibagi dengan total aset ${ }^{80}$. Selanjutnya, hutang jangka pendek hutang jangka pendek diukur dari kewajiban jangka pendek dibagi dengan total aset.

Besar kepemilikan institusional didapat dari presentase jumlah saham yang dimiliki institusi ${ }^{81}$. Ilmas et al., menjelaskan bahwa kepemilikan keluarga merupakan mereka yang

commissioners: Evidence from Indonesia. Research in World Economy. https://doi.org/10.5430/rwe.v11n3p108 ${ }^{79}$ Agustia, D. (2013). Pengaruh Faktor Good Corporate Governance, Free Cash Flow, dan Leverage Terhadap Manajemen Laba. Jurnal Akuntansi Dan Keuangan. https://doi.org/10.9744/jak.15.1.27-42

80 Thanh, S. D., Canh, N. P., \& Ha, N. T. T. (2020). Debt structure and earnings management: A non-linear analysis from an emerging economy. Finance Research Letters. https://doi.org/10.1016/j.frl.2019.08.031

81 Ismail, A. H., Abdul Rahman, A., \& Hezabr, A. A. (2018). Determinants of corporate environmental disclosure quality of oil and gas industry in developing countries. International Journal of Ethics and Systems. https://doi.org/10.1108/IJOES-03-2018-0042 
The Influence of Ownership Structure, Debt Structure, and

Independent Commissioner on Earning Management

anggota keluarganya merupakan pejabat, direktur, pemegang saham, baik individu atau sebagai kelompok ${ }^{82}$. Terakhir, besarnya kepemilikan didapatkan dari total saham manajemen (direksi, komisaris, dan manajer) dibagi dengan jumlah saham yang beredar.

\section{HASIL ANALISIS DATA}

\section{Uji Hipotesis}

Hasil regresi berganda dalam penelitian ini disajikan dalam tabel 2 berikut ini.

Tabel 2. Hasil Analisis Regresi Berganda

\begin{tabular}{crrrl}
\hline Variable & Coefficient & Std. Error & t-Statistic & Prob. \\
\hline C & $-3.75 E-05$ & 0.000571 & -0.065686 & 0.9477 \\
DKI & -0.000710 & 0.000802 & -0.884730 & 0.3773 \\
BOP & 0.000371 & 0.000493 & 0.753091 & 0.4523 \\
HJP & -0.000735 & 0.000219 & -3.352815 & 0.0010 \\
HJK & 0.001085 & 0.000324 & 3.351990 & 0.0010 \\
KIA & 0.000544 & 0.000327 & 1.665411 & 0.0974 \\
KK & -0.000267 & 0.000343 & -0.776718 & 0.4382 \\
KML & $-1.65 E-05$ & 0.000782 & -0.021159 & 0.9831 \\
\hline Root MSE & 0.000969 & R-squared & 0.082167 \\
Mean dependent var & 0.000230 & Adjusted R-squared & 0.050826 \\
S.D. dependent var & 0.001014 & S.E. of regression & 0.000987 \\
Sum squared resid & 0.000200 & F-statistic & 2.621740 \\
Durbin-Watson stat & 1.397856 & Prob(F-statistic) & 0.012961 \\
\hline
\end{tabular}

Sumber: Data Olah

Nilai adjusted $\mathrm{R}^{2}$ sebesar 0,050826 menunjukkan arti bahwa kemampuan menjelaskan variabel independen terhadap variabel dependen adalah 5,0826\%. Sisanya 94,9174 dipengaruhi oleh faktor lain diluar model regresi ini. Nilai probabilitas F-Statistik sebesar 0,012961 kurang dari 0,05 yang mengindikasikan bahwa model regresi yang digunakan dalam penelitian ini layak (fit) digunakan sebagai model pengujian hipotesis.

\section{Pembahasan}

\section{Pengaruh dewan komisaris independen terhadap earning management}

Hasil pengujian hipotesis ke satu $\left(\mathrm{H}_{1}\right)$ ditolak atau dewan komisaris independen tidak memiliki pengaruh terhadap earnings management. Hasil ini sejalan dengan peneitian yang dilakukan oleh Widyastuti ${ }^{83}$. Hal ini disebabkan oleh penambahan atau penempatan anggota dewan komisaris hanya sebatas untuk meningkatkan citra perusahaan dan pemenuhan regulasi saja. Selain itu, tidak ada tujuan untuk menegakkan tata kelola perusahaan yang baik. Nanda \& Somantri juga menemukan bahwa banyaknya perusahaan yang mengangkat dewan komisaris independen hanya sebatas pemenuhan kewajiban atas peraturan yang telah ditetapkan oleh bursa efek $^{84}$. Sementara faktanya adalah banyak dewan komisaris independen

\footnotetext{
82 Ilmas, F., Tahir, S., \& Asrar-ul-Haq, M. (2018). Ownership structure and debt structure as determinants of discretionary accruals: An empirical study of Pakistan. Cogent Economics and Finance. https://doi.org/10.1080/23322039.2018.1439254

83 Widyastuti, D. I. (2018). Pengaruh Kepemilikan Manajerial, Kepemilikan Institusional, dan Proporsi Dewan Komisaris Independen terhadap Manajemen Laba. JEBDEER: Journal of Entrepreneurship, Business Development and Economic Educations Research. https://doi.org/10.32616/jbr.v1i2.64

${ }^{84}$ Nanda, L. N., \& Somantri, Y. F. (2020). Pengaruh Komisaris Independen Terhadap Manajemen Laba Pada Perusahaan Bank Yang Terdaftar Di Bursa Efek Indonesia. Jrka
} 
tidak memiliki kemampuan dalam menjalankan independensinya dengan baik. Selanjutnya, di Indonesia sering terjadi aktivitas anggota dewan komisaris independen yang tidak bertindak aktif dan menjalankan fungsi pengawaasnnya yang menjadi awal tanggung jawab terhadap dewan direksi ${ }^{85}$.

\section{Pengaruh blockholder ownership terhadap earning management}

Hasil pengujian hipotesis ke dua $\left(\mathrm{H}_{2}\right)$ ditolak atau blockholder ownership tidak berpengaruh terhadap earnings management. Hasil ini sama dengan penelitian Zulvina ${ }^{86}$. Blockholder ownership tidak memiliki pengaruh pada earning management karena tidak mendapatkan wewenang lebih dari perusahaan untuk memengaruhi berbagai aspek dalam pergerakan dan keputusan perusahaan daripada pemegang saham biasa ${ }^{87}$. Hal ini menjelaskan bahwa blockholder ownership tidak dapat memengaruhi tingkat earnings management pada perusahaan non keungan di Bursa Efek Indonesia.

\section{Pengaruh hutang jangka panjang terhadap earnings management}

Hasil pengujian hipotesis ke tiga $\left(\mathrm{H}_{3 a}\right)$ diterima atau hutang jangka panjang berpengaruh negatif pada earnings management. Hasil ini sama dengan penelitian yang dilakukan oleh Christiawan \& Rahmiati yakni tingkat hutang jangka panjang yang tinggi dapat meningkatkan pengawasan dari pihak peminjam, sehingga debitur akan tetap menjaga hubungan dengan baik dengan peminjam ${ }^{88}$. Perusahaan sebagai debitur akan menghindari pelanggaran perjanjian dalam kontrak hutang karena akan menimbulkan sanksi dari kreditur berupa larangan dividen atau aplikasi hutang baru yang akhirnya menghambat aktivitas manajer untuk melakukan bisnis mereka. Hal ini sesuai dengan prinsip shari'ab enterprise theory bahwa semakin tinggi hutang yang dipinjamkan khususnya pada kasus hutang jangka panjang yang jumlahnya besar, maka manusia sebagai stakeholder kedua menjalankan hukum-hukum Allah (stakeholder pertama) yaitu tidak melakukan pelanggaran atau kecurangan sebagai bentuk akuntabilitas atau pertanggungjawaban.

\section{Pengaruh hutang jangka pendek terhadap earning management}

Hasil pengujian hipotesis ke tiga $\left(3_{\mathrm{b}}\right)$ diterima atau hutang jangka pendek memiliki pengaruh positif terhadap earnings management. Hasil ini sama dengan penelitian yang dilakukan oleh Fung \& Goodwin dan Ilmas et al. ${ }^{89}$ Hasil ini mengungkapkan bahwa di Indonesia kreditur perusahaan tertarik untuk memantau aktivitas hutang jangka pendek dan skenario ini lebih memfasilitasi pihak manajemen untuk melakukan earnings management. Selain itu, suatu badan usaha jika semakin dekat dengan pelanggaran perjanjian kontrak maka earnings management yang dilakukan oleh badan usaha tersebut tinggi. Selanjutnya, hutang jangka pendek menginduksi earnings management lebih besar dikarenakan badan usaha yang sedang mengalami krisis akan memacu badan usaha untuk memperbaiki keadaan.

\section{Pengaruh kepemilikan institusional terhadap earning management}

Hasil pengujian hipotesis ke empat $\left(\mathrm{H}_{4}\right)$ ditolak atau kepemilikan institusional tidak berpengaruh terhadap earnings management. Hasil ini sama dengan hasil penelitian yang

\footnotetext{
85 Yendrawati, R. (2015). Pengaruh Dewan Komisaris Independen, Komite Audit, Kepemilikan Manajerial, dan Kepemilikan Institusional terhadap Manajemen Laba. Jurnal Entrepreneur Dan Entrepreneurship.

${ }^{86}$ Zulvina, Y. (2015). Pengaruh Komisaris Independen, Komite Audit dan Blockholders Terhadap Earnings Management. Jom FEKON

87 Wirawardhana, I., \& Sitardja, M. (2018). Analisis Pengaruh Kepemilikan Blockholder, Kepemilikan Manajerial, Kepemilikan Institusional, dan Komite Audit terhadap Nilai Perusahaan. Indonesian Journal of Accounting and Governance. https://doi.org/10.36766/ijag.v2i1.10

88 Christiawan, Y. J., \& Rahmiati, A. (2015). Earnings Management of Firms Reporting Long Term Debt: An Alternative Method. Jurnal Akuntansi Dan Keuangan. https://doi.org/10.9744/jak.16.2.113-120

${ }^{89}$ Fung, S. Y. K., \& Goodwin, J. (2013). Short-term debt maturity, monitoring and accruals-based earnings management. Journal of Contemporary Accounting and Economics. https://doi.org/10.1016/j.jcae.2013.01.002
} 
The Influence of Ownership Structure, Debt Structure, and

Independent Commissioner on Earning Management

dilakukan oleh Mahariana \& Ramantha, Purnama, dan Saftiana et al. ${ }^{909192}$ Hal ini menjelaskan bahwa semakin tingginya atau rendahnya porsi kepemilikan institusional tidak terlalu berarti sebagai suatu cara untuk memonitoring tindakan internal yang menjalankan kecurangan berupa earnings management. Selain itu, investor institusional tidak bertindak sebagai sophisticated investor yang memiliki lebih banyak kemampuan dan peluang untuk melakukan pengawasan dan mendisiplinkan manajer, sehingga lebih berfokus pada nilai perusahaan ${ }^{93}$.

\section{Pengaruh kepemilikan keluarga terhadap earning management}

Hasil pengujian hipotesis ke lima $\left(\mathrm{H}_{5}\right)$ ditolak atau kepemilikan keluarga tidak berpengaruh terhadap earnings management. Hasil ini sejalan dengan penelitian yang dilakukan oleh Kurnia et al. (2015). Hal ini dimungkinkan bahwa pihak kreditur cenderung memilih untuk tidak memperhatikan tingkat proporsi kepemilikan keluarga dalam pengambilan keputusan hutang yang ditanggung oleh perusahaan ${ }^{94}$.

\section{Pengaruh kepemilikan manajerial terhadap earning management}

Hasil pengujian hipotesis ke enam $\left(\mathrm{H}_{6}\right)$ ditolak atau kepemilikan manajerial tidak berpengaruh pada earnings management. Hasil ini sesuai dengan penelitian Yendrawati. Ratarata kepemilikan saham yang dimiliki pihak manajemen perusahaan dari hasil statistik sebesar 0,061201 lebih dari 5\% masih dianggap kecil, sehingga para manajer yang juga pemilik saham perusahaan akan lebih memilih kebijakan untuk mengelola laba dengan sudut pandang keinginan investor. Wujud kebijakannya yaitu dengan meningkatkan laba yang dilaporkan dan akhirnya banyak investor terpengaruh untuk menanam modal yang berimbas pada kenaikan harga saham perusahaan ${ }^{95}$.

\section{Simpulan, Keterbatasan, dan Saran}

Hasil pengujian hipotesis menunjukkan struktur kepemilikan, struktur hutang, dan dewan komisaris independen berpengaruh terhadap earnings management, sehingga dapat disimpulkan sebagai berikut: Dewan Komisaris Independen tidak berpengaruh terhadap earnings management. Hal ini disebabkan karena komisaris independen hanya difungsikan untuk meningkatkan citra perusahaan dan pemenuhan regulasi saja. Blockholder Ownership tidak berpengaruh terhadap earnings management. Penyebab hal ini adalah tidak didapatkannya wewenang secara penuh oleh blockholder sehingga tidak mampu memengaruhi aspek pergerakan perusahaan. Hutang Jangka Panjang berpengaruh negatif terhadap earnings management. Semakin tinggi jumlah hutang jangka panjang, semakin tinggi pengawasan dari pihak kreditur yang akhirnya mengurangi motivasi peminjam untuk melakukan earnings management. Hutang Jangka Pendek berpengaruh positif terhadap earnings management. Hal ini dapat terjadi karena di Indonesia kreditur perusahaan lebih tertarik untuk memantau aktivitas hutang jangka pendek dan skenario ini lebih memfasilitasi pihak manajemen ke arah earnings

\footnotetext{
90 Mahariana, I. D. G. P., \& Ramantha, I. W. (2014). Pengaruh Kepemilikan Manajerial dan Kepemilikan Institusional Pada Manajemen Laba Perusahaan Manufaktur di Bursa Efek Indonesia. E-Jurnal Akuntansi.

${ }^{1}$ Purnama, D. (2017). Pengaruh Profitabilitas, Leverage, Ukuran Perusahaan, Kepemilikan Institusional, dan Kepemilikan Manajerial Terhadap Manajemen Laba. Jurnal Riset Kenangan Dan Akuntansi. https://doi.org/10.25134/jrka.v3i1.676

92 Saftiana, Y., Mukhtaruddin, Putri, K. W., \& Ferina, I. S. (2017). Corporate governance quality, firm size and earnings management: Empirical study in Indonesia stock exchange. Investment Management and Financial Innovations. https://doi.org/10.21511/imfi.14(4).2017.10

93 Yendrawati, R. (2015). Pengaruh Dewan Komisaris Independen, Komite Audit, Kepemilikan Manajerial, dan Kepemilikan Institusional terhadap Manajemen Laba. Jurnal Entrepreneur Dan Entrepreneurship

94 Rebecca, Y., \& Siregar, S. V. (2012). Pengaruh corporate governance index, kepemilikan keluarga, dan kepemilikan institusional terhadap biaya ekuitas dan biaya utang: studi empiris pada .... Simposium Nasional Akuntansi XV.

95 Agustia, D., Muhammad, N. P. A., \& Permatasari, Y. (2020). Earnings management, business strategy, and bankruptcy risk: evidence from Indonesia. Heliyon. https://doi.org/10.1016/j.heliyon.2020.e03317
} 
management. Kepemilkan Institusional tidak berpengaruh terhadap earnings management. Tingkat porsi kepemilikan saham yang dimiliki institusi tidak begitu berarti sebagai suatu cara untuk memonitoring aktivitas internal perusahaan yang melakukan earnings management. Kepemilikan Keluarga tidak berpengaruh terhadap earnings management. Kekayaan sosio emosional yang dimiliki keluarga di perusahaannya membuat anggota keluarga ingin selalu menjaga reputasi perusahaan dan tidak akan terlibat dalam earnings management. Kepemilikan Manajerial tidak berpengaruh terhadap earnings management. Total saham yang dimiliki pihak manajer tidak mampu memengaruhi besar kecilnya nilai earnings management yang dilakukan oleh perusahaan.

Dalam penelitian ini terdapat keterbatasan karena tahun pengamatannya hanya pada 2017-2019, dan perusahaan non keuangan yang diteliti hanya sektor barang baku, energi, perindustrian, dan konsumen primer. Selanjutnya penelitian yang akan datang untuk dapat menambahkan sampel yang terdiri dari semua sektor perusahaan non keuangan yang terdaftar di Bursa Efek di Indonesia dan dapat menambah variabel lain yang dapat berpengaruh pada earnings management seperti: rapat dewan, masa jabatan auditor, dan reputasi auditor.

\section{Daftar Pustaka}

Abdullah, Y., \& Nugraha, A. W. (2020). Implementasi Akuntabilitas Berdasarkan Pada Perspektif Sharia Enterprise Theory (Studi Kasus pada Koperasi Syariah Mumtaz Tasikmalaya). Jurnal Ekonomi Syariah.

Achleitner, A. K., Günther, N., Kaserer, C., \& Siciliano, G. (2014). Real earnings management and accrual-based earnings management in family firms. European Accounting Review. https://doi.org/10.1080/09638180.2014.895620

Affan, M., Ak, R., \& Purwanti, L. (2017). The Effect of Ownership Structure on the Quality of Financial Reporting Of Manufacturing Companies Listed In the IDX during the Period of 2013-2015. Imperial Journal of Interdisciplinary Research (IJIR).

Agustia, D. (2013). Pengaruh Faktor Good Corporate Governance, Free Cash Flow, dan Leverage Terhadap Manajemen Laba. Jurnal Akuntansi Dan Keuangan. https://doi.org/10.9744/jak.15.1.27-42

Agustia, D., Muhammad, N. P. A., \& Permatasari, Y. (2020). Earnings management, business strategy, and bankruptcy risk: evidence from Indonesia. Heliyon. https://doi.org/10.1016/j.heliyon.2020.e03317

Alexander, N. (2019). Ownership Structure and Earnings Management. GATR Accounting and Finance Review. https://doi.org/10.35609/afr.2019.4.2(1)

Alhadab, M., Abdullatif, M., \& Mansour, I. (2020). Related party transactions and earnings management in Jordan: the role of ownership structure. Journal of Financial Reporting and Accounting. https://doi.org/10.1108/JFRA-01-2019-0014

Amir,Hasnah, A. (2018). Family Ownership And Real Earnings Management. Journal of Global Business and Social Entrepreneurship (GBSE), 4, 9-16. https://www.researchgate.net/publication/325118582_Family_Ownership_And_Rea 1_Earnings_Management/link/5af903760f7e9b026bf6ca88/download

Anwar, H., \& Buvanendra, S. (2019). Earnings Management and Ownership Structure: Evidence from Sri Lanka Colombo Business Journal. https://doi.org/10.4038/cbj.v10i1.42

Asiriuwa, O., Akperi, R. T., Uwuigbe, O. R., Uwuigbe, U., Nassar, L., Ilogho, S., \& Eriabe, S. (2019). Ownerships Structures and Accounting Conservatism among Nigeria Listed Firms. IOP Conference Series: Earth and Environmental Science. https://doi.org/10.1088/1755-1315/331/1/012056

Astuti, E. (2015). Pengaruh Kepemilikan Institusional, Profitabilitas, Ukuran Perusahaan 
The Influence of Ownership Structure, Debt Structure, and

Independent Commissioner on Earning Management

Terhadap Kebijakan Hutang Perusahaan di Indonesia. Jurnal Akuntansi Dan Pajak. https://doi.org/10.29040/jap.v15i02.188

Bao, S. R., \& Lewellyn, K. B. (2017). Ownership structure and earnings management in emerging markets-An institutionalized agency perspective. International Business Review. https://doi.org/10.1016/j.ibusrev.2017.02.002

Bathala, C. T., Moon, K. P., \& Rao, R. P. (1994). Managerial Ownership, Debt Policy, and the Impact of Institutional Holdings: An Agency Perspective. Financial Management. https://doi.org/10.2307/3665620

Bendickson, J., Muldoon, J., Liguori, E., \& Davis, P. E. (2016). Agency theory: the times, they are a-changin'. Management Decision. https://doi.org/10.1108/MD-02-2015-0058

Boone, A. L., \& White, J. T. (2015). The effect of institutional ownership on firm transparency and information production. Journal of Financial Economics. https://doi.org/10.1016/j.jfineco.2015.05.008

Christiawan, Y. J., \& Rahmiati, A. (2015). Earnings Management of Firms Reporting Long Term Debt: An Alternative Method. Jurnal Akuntansi Dan Keuangan. https://doi.org/10.9744/jak.16.2.113-120

Dang, N. H., Hoang, T. V. H., \& Tran, M. D. (2017). Factors affecting earnings management: The case of listed firms in Vietnam. International Journal of Economic Research.

Dixon, R., Guariglia, A., \& Vijayakumaran, R. (2017). Managerial ownership, corporate governance and firms' exporting decisions: Evidence from Chinese listed companies. European Journal of Finance. https://doi.org/10.1080/1351847X.2015.1025990

Edmans, A. (2014). Blockholders and corporate governance. In Annual Review of Financial Economics. https://doi.org/10.1146/annurev-financial-110613-034455

Eisenhardt, K. M. (1989). Agency Theory: An Assessment and Review. Academy of Management Review. https://doi.org/10.5465/amr.1989.4279003

Emmanuel, P., , Umoh, R. O., Afor, H., Roselyn, Zakaria sabe Zainab, \& . (2019). Effect of Ownership Structure on Earnings Management of Listed Industrial Goods Companies in Nigeria. Journal of Business and Management (IOSR-JBM).

Fung, S. Y. K., \& Goodwin, J. (2013). Short-term debt maturity, monitoring and accrualsbased earnings management. Journal of Contemporary Accounting and Economics. https://doi.org/10.1016/j.jcae.2013.01.002

Ghazali, A. W., Shafie, N. A., \& Sanusi, Z. M. (2015). Earnings Management: An Analysis of Opportunistic Behaviour, Monitoring Mechanism and Financial Distress. Procedia Economics and Finance. https://doi.org/10.1016/s2212-5671(15)01100-4

Haider, W. (2020). Factors Affecting Earnings Management: Evidence From Banking Sectors Of Pakistan. International Journal of Scientific \& Engineering Research.

Halioui, K., \& Jerbi, A. (2012). The effect of blockholders on earnings-management: the case of Tunisian listed firms. International Journal of Multidisciplinary Research,.

Handriani, E. (2020). Earning management and the effect characteristics of audit committee, independent commissioners: Evidence from Indonesia. Research in World Economy. https://doi.org/10.5430/rwe.v11n3p108

Hapsoro, D., \& Bahantwelu, M. I. (2020). Does earning management mediate the effect of capital structure on company value? Jurnal Ekonomi Dan Bisnis. https://doi.org/10.24914/jeb.v23i1.2531

Haryono, S. (2017). Struktur Kepemilikan dalam Bingkai Teori Keagenan. Jurnal Akuntansi \& Bisnis.

Hsu, M.-F., \& Wen, S.-Y. (2015). The Influence of Corporate Governance in Chinese Companies on Discretionary Accruals and Real Earnings Management. Asian Economic and Financial Review. https://doi.org/10.18488/journal.aefr/2015.5.3/102.3.391.406 
Ilmas, F., Tahir, S., \& Asrar-ul-Haq, M. (2018). Ownership structure and debt structure as determinants of discretionary accruals: An empirical study of Pakistan. Cogent Economics and Finance. https://doi.org/10.1080/23322039.2018.1439254

Ismail, A. H., Abdul Rahman, A., \& Hezabr, A. A. (2018). Determinants of corporate environmental disclosure quality of oil and gas industry in developing countries. International Journal of Ethics and Systems. https:/ / doi.org/10.1108/IJOES-03-2018-0042

Jensen, M. C., \& Meckling, W. H. (1976). Theory of the firm: Managerial behavior, agency costs and ownership structure. Journal of Financial Economics. https://doi.org/10.1016/0304-405X(76)90026-X

Jerbi Maatougui, A., \& Halioui, K. (2019). The effect of outside blockholders on earnings management around seasoned equity offerings in French listed companies on the SBF120. Journal of Financial Reporting and Accounting. https://doi.org/10.1108/JFRA-022018-0012

Jiang, F., Ma, Y., \& Wang, X. (2020). Multiple blockholders and earnings management. Journal of Corporate Finance. https://doi.org/10.1016/j.jcorpfin.2020.101689

Kapkiyai, C., Cheboi, J., \& Komen, J. (2020). Shareholder Activism and Earnings Management: Evidence from Kenya. African Journal of Education, Science and Technology.

Khan, M., Srinivasan, S., \& Tan, L. (2017). Institutional ownership and corporate tax avoidance: New evidence. Accounting Review. https://doi.org/10.2308/accr-51529

Kjærland, F., Haugdal, A. T., Søndergaard, A., \& Vågslid, A. (2020). Corporate Governance and Earnings Management in a Nordic Perspective: Evidence from the Oslo Stock Exchange. Journal of Risk and Financial Management. https://doi.org/10.3390/jrfm13110256

Kurmann, A., Keller, S., Tschan-Semmer, F., Seelandt, J., Semmer, N. K., Candinas, D., \& Beldi, G. (2014). Impact of team familiarity in the operating room on surgical complications. World Journal of Surgery. https://doi.org/10.1007/s00268-014-2680-2

Kurnia, P., Azlina, N., \& Rezeki, S. (2015). Pengaruh Kepemilikan Keluarga, Praktek Good Corporate Governance, Profitabilitas Terhadap Manajemen Laba Pada Perusahaan Listing di Bursa Efek Indonesia 2008-2012. Jurnal Online Mabasiswa Fakultas Ekonomi Universitas Riau.

Lassoued, N., Attia, M. B. R., \& Sassi, H. (2018). Earnings management in islamic and conventional banks: Does ownership structure matter? Evidence from the MENA region. Journal of International Accounting, Auditing and Taxation. https://doi.org/10.1016/j.intaccaudtax.2017.12.003

Latif, A. \&, \& Abdullah Fahad. (2015). The Effectiveness of Corporate Governance in Constraining Earnings Management in Pakistan. The Lahore Journal of Economics.

Laut, I. M. (2020). The Beauty and the Beast of Earning Management in Indonesia. Opción, 31, 19. https://www.produccioncientificaluz.org/index.php/opcion/article/view/32496/339 59

Lin, Y. R., \& Fu, X. M. (2017). Does institutional ownership influence firm performance? Evidence from China. International Review of Economics and Finance. https://doi.org/10.1016/j.iref.2017.01.021

Lskavyan, V., \& Spatareanu, M. (2011). Shareholder protection, ownership concentration and FDI. Journal of Economics and Business. https://doi.org/10.1016/j.jeconbus.2010.05.002

Mahariana, I. D. G. P., \& Ramantha, I. W. (2014). Pengaruh Kepemilikan Manajerial dan Kepemilikan Institusional Pada Manajemen Laba Perusahaan Manufaktur di Bursa Efek Indonesia. E-Jurnal Akuntansi. 
The Influence of Ownership Structure, Debt Structure, and

Independent Commissioner on Earning Management

Marrakchi Chtourou, S., Bdard, J., \& Courteau, L. (2005). Corporate Governance and Earnings Management. SSRN Electronic Journal. https://doi.org/10.2139/ssrn.275053

Martin, G., Campbell, J. T., \& Gomez-Mejia, L. (2016). Family Control, Socioemotional Wealth and Earnings Management in Publicly Traded Firms. Journal of Business Ethics. https://doi.org/10.1007/s10551-014-2403-5

Maulana, Z., \& Safa, A. F. (2017). Pengaruh Hutang Jangka Pendek Dan Hutang Jangka Panjang Terhadap Profitabilitas Pada PT. Bank Mandiri Tbk. Penelitian Ekonomi Akuntansi.

Miller, D., Breton-Miller, I. Le, \& Lester, R. H. (2010). Family ownership and acquisition behavior in publicly-traded companies. Strategic Management Journal. https://doi.org/10.1002/smj.802

Nanda, L. N., \& Somantri, Y. F. (2020). Pengaruh Komisaris Independen Terhadap Manajemen Laba Pada Perusahaan Bank Yang Terdaftar Di Bursa Efek Indonesia. Jrka.

Nguyen, L. (2020). Short Term Debt Maturity, Real Earnings Management and Firm Performance Short Term Debt Maturity, Real Earnings Management and Firm Performance. May.

Novi Lidiawati, N. F. A. (2016).Pengaruh Kualitas Audit, Komite Audit, Kepemilikan Institusional, Ukuran Perusahaan Terhadap Manajemen Laba. Ilmu Dan Riset Akuntansi, 5. http://jurnalmahasiswa.stiesia.ac.id/index.php/jira/article/view/1737/1747

O'Callaghan, S., Ashton, J., \& Hodgkinson, L. (2018). Earnings management and managerial ownership in private firms. Journal of Applied Accounting Research. https://doi.org/10.1108/JAAR-11-2017-0124

Öhman, P., \& Yazdanfar, D. (2017). Short- and long-term debt determinants in Swedish SMEs. Review of Accounting and Finance. https://doi.org/10.1108/RAF-08-2015-0118

Oktaviani, H. D. (2015). Pengaruh Ukuran Dewan Direksi, Proporsi Dewan Komisaris Independen, dan Ukuran Komite Audit terhadap Praktik Manajemen Laba pada Perusahaan Farmasi. PhD Proposal.

Palacios-Manzano, M., Gras-Gil, E., \& Santos-Jaen, J. M. (2021). Corporate social responsibility and its effect on earnings management: an empirical research on Spanish firms. In Total Quality Management and Business Excellence. https://doi.org/10.1080/14783363.2019.1652586

Park, S. Y. (2016). The effect of short-term debt on accrual based earnings management and real earnings management. Journal of Applied Business Research. https://doi.org/10.19030/jabr.v32i4.9737

Parveen, S., Malik, N., Mahmood, Y., \& Ali Jan, F. (2016). Impact of Ownership Structure on Earnings Management: Evidence from Pakistani Banking Sector. An International Peer-Reviewed Journal.

Pernamasari, R., Purwaningsih, S., Tanjung, J., \& Rahayu, D. P. (2020). Effectiveness Of Firm Performance And Earnings Management To Stock Prices. EPRA International Journal of Multidisciplinary Research (IJMR). https://doi.org/10.36713/epra3922

Prakasa, S. U. W. (2019). Garuda Indonesia-Rolls Royce Corruption, Transnational Crime, and Eradication Measures. Lentera Hukum. https://doi.org/10.19184/ejlh.v6i3.14112

Pramiana, O., \& Anisah, N. (2018). Implementasi Corporate Social Responsibility (CSR) Dalam Perspektif Shariah Enterprise Theory. EKSIS.

Pucheta-Martínez, M. C., \& García-Meca, E. (2014). Institutional investors on boards and audit committees and their effects on financial reporting quality. Corporate Governance: An International Review. https://doi.org/10.1111/corg.12070

Purnama, D. (2017). Pengaruh Profitabilitas, Leverage, Ukuran Perusahaan, Kepemilikan Institusional, dan Kepemilikan Manajerial Terhadap Manajemen Laba. Jurnal Riset Keuangan Dan Akuntansi. https://doi.org/10.25134/jrka.v3i1.676 
Puspitasari Puji, Emy., D. (2019). Pengaruh Faktor Good Corporate Governance, Free Cash Flow, dan Leverage Terhadap Manajemen Laba Pada Perusahaan Batu Bara. E-Jra.

Rashid, A. (2016). Managerial Ownership and Agency Cost: Evidence from Bangladesh. Journal of Business Ethics. https://doi.org/10.1007/s10551-015-2570-z

Rebecca, Y., \& Siregar, S. V. (2012). Pengaruh corporate governance index, kepemilikan keluarga, dan kepemilikan institusional terhadap biaya ekuitas dan biaya utang: studi empiris pada .... Simposium Nasional Akuntansi XV.

Rey, A., Tuccillo, D., \& Roberto, F. (2020). Earnings management and debt maturity: Evidence from Italy. Corporate Ownership and Control. https://doi.org/10.22495/cocv17i3art14

Robin, \& Amran, N. A. (2016). The effect of board of commissioners on family firms performance in Indonesia. Advanced Science Letters. https://doi.org/10.1166/asl.2016.8083

Roodposhti, F. R., \& Chashmi, S. A. N. (2011). The impact of corporate governance mechanisms on earnings management. African Journal of Business Management, 5(11), 4143-4151. https://doi.org/10.5897/AJBM10.471

Saftiana, Y., Mukhtaruddin, Putri, K. W., \& Ferina, I. S. (2017). Corporate governance quality, firm size and earnings management: Empirical study in Indonesia stock exchange. Investment Management and Financial Innovations. https://doi.org/10.21511/imfi.14(4).2017.10

Saleh, I., Afifa, M. A., \& Haniah, F. (2020). Financial factors affecting earnings management and earnings quality: New evidence from an emerging market. ACRN Journal of Finance and Risk Perspectives. https://doi.org/10.35944/JOFRP.2020.9.1.014

San Martin Reyna, J. M. (2018). The effect of ownership composition on earnings management: evidence for the Mexican stock exchange. Journal of Economics, Finance and Administrative Science. https://doi.org/10.1108/JEFAS-01-2017-0011

Saona, P., Muro, L., \& Alvarado, M. (2020). How do the ownership structure and board of directors' features impact earnings management? The Spanish case. Journal of International Financial Management and Accounting. https://doi.org/10.1111/jifm.12114

Scott, W. R. (2015). Financial Accounting Theory 7th Edition. In Financial Accounting Theory.

Shah, K., \& Shah, A. (2014). The Impact of Corporate Governance and Ownership Structure on Earnings Management Practices: Evidence from Listed Companies in Pakistan. The Lahoure Journal of Economics. https://doi.org/10.35536/lje.2014.v19.i2.a2

Sila, V., Gonzalez, A., \& Hagendorff, J. (2017). Independent director reputation incentives and stock price informativeness. Journal of Corporate Finance. https://doi.org/10.1016/j.jcorpfin.2017.09.018

Surya, B. J. M. H. (2017). Studi Pengaruh Short-Term Debt Dan Earnings Management Pada Badan Usaha Yang Terdaftar Di Bei Dan Pefindo Tahun 2011 - 2013. Jurnal Ilmiah Mahasiswa Universitas Surabaya.

Susanto, Y. K. (2016). The Effect of Audit Committees and Corporate Governance on Earnings Management: Evidence From Indonesia Manufacturing Industry. International Journal of Business, Economics and Law.

Syahreza, F., Pratomo, D., \& Yudowati, S. (2016). Pengaruh Komisaris Independen dan Komite Audit Terhadap Manajemen Laba ( Studi Empiris Pada Perusahaan Manufakur Sub Sektor Makanan dan Minuman yang Terdaftar di dalam Bursa Efek Indonesia Tahun 2010-2013 ). E-Proceeding of Management.

Thanh, S. D., Canh, N. P., \& Ha, N. T. T. (2020). Debt structure and earnings management: A non-linear analysis from an emerging economy. Finance Research Letters. https://doi.org/10.1016/j.frl.2019.08.031 
The Influence of Ownership Structure, Debt Structure, and

Independent Commissioner on Earning Management

Thomsen, S., Pedersen, T., \& Kvist, H. K. (2006). Blockholder ownership: Effects on firm value in market and control based governance systems. Journal of Corporate Finance. https://doi.org/10.1016/j.jcorpfin.2005.03.001

Tiaras, I., \& Wijaya, H. (2017). Pengaruh Likuiditas, Leverage, Manajemen Laba, Komisaris Independen dan Ukuran Perusahaan Terhadap Agresivitas Pajak. Jurnal Akuntansi. https://doi.org/10.24912/ja.v19i3.87

Trung, T. Q., Liem, N. T., \& Thuy, C. T. M. (2020). The impact of short-term debt on accruals-based earnings management-evidence from Vietnam. Cogent Economics and Finance, 8(1). https://doi.org/10.1080/23322039.2020.1767851

Ung, L. J., Brahmana, R. K., \& Puah, C. H. (2018). Brokerage fee, ownership expropriation and earnings management of Malaysian property companies. Property Management. https://doi.org/10.1108/PM-06-2017-0035

Vijayakumaran, R. (2021). Impact of managerial ownership on investment and liquidity constraints: Evidence from Chinese listed companies. Research in International Business and Finance. https://doi.org/10.1016/j.ribaf.2020.101321

Wahidah, S. A., \& Ardiansari, A. (2019). The Effect of Board of Commissioners and Independent Commissioners on Agency Cost Through Capital Structure. Management Analysis Journal.

Wang, H. Da, \& Lin, C. J. (2013). Debt financing and earnings management: An internal capital market perspective. Journal of Business Finance and Accounting. https://doi.org/10.1111/jbfa.12030

Widyastuti, D. I. (2018). Pengaruh Kepemilikan Manajerial, Kepemilikan Institusional, dan Proporsi Dewan Komisaris Independen terhadap Manajemen Laba. JEBDEER: Journal of Entrepreneurship, Business Development and Economic Educations Research. https://doi.org/10.32616/jbr.v1i2.64

Wiliandri, R. (2011). Pengaruh blockholder ownership dan firm size terhadap kebijakan utang perusahaan. Jurnal Ekonomi Bisnis.

Wirawardhana, I., \& Sitardja, M. (2018). Analisis Pengaruh Kepemilikan Blockholder, Kepemilikan Manajerial, Kepemilikan Institusional, dan Komite Audit terhadap Nilai Perusahaan. Indonesian Journal of Accounting and Governance. https://doi.org/10.36766/ijag.v2i1.10

Wulandari, S., \& Suganda, A. D. (2021). Determining factors of earnings management based on accrual model. Jurnal Akuntansi \& Auditing Indonesia. https://doi.org/10.20885/jaai.vol25.iss1.art5

Yahaya, I. D., Oyedokun, G. E., \& Aruwa, S. A. S. (2019). Effect of ownership structure on earnings management of listed consumer goods firms in Nigeria. Fountain University Osogbo Journal of Management.

Yendrawati, R. (2015). Pengaruh Dewan Komisaris Independen, Komite Audit, Kepemilikan Manajerial, dan Kepemilikan Institusional terhadap Manajemen Laba. Jurnal Entrepreneur Dan Entrepreneurship.

Zakia, V., Diana, N., \& Mawardi, M. C. (2019). Pengaruh Kepemilikan Manajerial, Kepemilikan Institusional, Ukuran Perusahaan, Leverage, Profitabilitas, Pertumbuhan Penjualan Terhadap Manajemen Laba Dengan Good Corporate Governance Sebagai Variabel Moderating. E-Jounal Riset Akuntansi.

Zulvina, Y. (2015). Pengaruh Komisaris Independen, Komite Audit dan Blockholders Terhadap Earnings Management. Jom FEKON.

https://quranindo.com/surat-al-mutaffifin/

http://www.ibnukatsironline.com/2015/10/tafsir-surat-al-muthaffifin-ayat-1-6.html 